\title{
Soil Organisms Effect on Leaf Litter Decomposition of Four Selected Plant Species in the Sudano-Guinea Savannahs of Ngaoundere, Cameroon
}

\author{
Babe Ndara Grégoire ${ }^{1, ~ *, ~ M a s s a i ~ T c h i m a ~ J a c o b ~}{ }^{1,2}$, Maigari Pale ${ }^{1}$, Ibrahima Adamou ${ }^{1}$ \\ ${ }^{1}$ Department of Biological Sciences, Ngaoundere University, Ngaoundere, Cameroon \\ ${ }^{2}$ Wakwa Regional Research Centre, Institute of Agriculture Research for Development (IRAD), Ngaoundere, Cameroon
}

Email address:

babegregoire@gmail.com(B. N. Grégoire)

${ }^{*}$ Corresponding author

\section{To cite this article:}

Babe Ndara Grégoire, Massai Tchima Jacob, Maigari Pale, Ibrahima Adamou. Soil Organisms Effect on Leaf Litter Decomposition of Four Selected Plant Species in the Sudano-Guinea Savannahs of Ngaoundere, Cameroon. Ecology and Evolutionary Biology.

Vol. 5, No. 2, 2020, pp. 13-21. doi: 10.11648/j.eeb.20200502.11

Received: May 25, 2020; Accepted: June 28, 2020; Published: July 30, 2020

\begin{abstract}
Few studies were carried out on the influence of soil organisms on the litter decomposition in savannahs of Adamawa, Cameroon. The goal of this study is to determine the total influence of the soil organisms on the litter decomposition of four important socio-economic species of sudano-guinea savannahs of Ngaoundere. These species are Terminalia glaucescens, Ficus sycomorus, Hymenocardia acida and Daniellia oliveri. The experimentation was carried out in situ using the litterbags method in two plots, treated and control with the insecticide naphthalene. 72 litterbags of $10 \pm 0,01 \mathrm{~g}$ each one were incubated in each of the 2 plots during 24 weeks. A taking away of 3 samples of each species was carried out at $2,4,6,10,16$ and 24 weeks. The soil organisms were also sampled at 12 and 24 weeks of incubation. At the end of the experiment, nine taxonomic groups were collected in the two plots during $12^{\text {th }}$ and the $24^{\text {th }}$ week of incubation. The control plot has a total taxonomic composition of fauna (9 groups) and an average of total density $\left(426.25 \mathrm{ind} . / \mathrm{m}^{2}\right)$ higher than that treated $\left(8\right.$ groups and 362.50 ind. $\left./ \mathrm{m}^{2}\right)$. At the end of incubation, the total remaining dry mass is significantly lower in the control plot $(9 \%)$ than in that treated $(42 \%)$. By species, this remaining dry mass and the rate of litters decomposition differ significantly between the two plots for all the species, except for that of Terminalia glaucescens. The number and the density of the soil organisms obtained in control plot where higher than that obtained in treated plot. The soil organisms thus influence the litter decomposition in savannahs of Ngaoundere, but this influence is varying according to the species and the time of incubation. These results could contribute to the management of the fertility of the soil in savannahs in general and those of Ngaoundere in particular.
\end{abstract}

Keywords: Soil Organisms, Litter Decomposition, Multiple Uses Species, Savannahs of Ngaoundere, Cameroon

\section{Introduction}

The tropical world in general and sub-Saharan Africa in particular faces a demographic growth which involves an unceasingly increasing pressure on the natural ecosystems [1, 2]. The anthropic pressure on vegetable cover is responsible for the climatic change and impoverishment of the soil [3]. Sudano-guinea savannahs of Cameroon are diversified and rich in species of socio-economic interest [4], but the current demographic growth also meant their degradation through the anarchistic wood cut, the overgrazing, agriculture on burned and pastoral fires [5, 6]. These effects are translated by the impoverishment of the organic matter reserve in soil and loss of nutrient content [5]. This could lead to poor yield of the crops, which goes to increased food insecurity; and the long-term starvation. Currently, to rectify this situation, it appears necessary to consider in the local country mediums the sustainable management and rational exploitation of soil [7] and to increase the agricultural production while preserving the natural ecosystems [8]. This sustainable management of the soil means that its exploitation must be compensated by contributions, so that dynamic balance is 
maintained. Woody plant species used in agroforestry may be involved in increasing the productivity on site, through the ecological and physico-chemical changes that they induce in the soil through their litter rich in nutrient such as nitrogen, phosphorus, potassium, magnesium and carbon [9].

The change of this organic matter died by their decomposition leads to a release of energy, carbon dioxide and nutrient in the soil in to available form for plants [10, 11]. The rate of litter decomposition is a factor that largely determines the fertility of the soil [12] and its regulation and its regulation plays an important role in the functioning of agro-ecosystems, especially in poor soils like those of Sudano-guinea savannahs of Ngaoundere [13].

Studies showed that the process of litter decomposition is influenced by the physicochemical properties of the litters as their nitrogen content, carbon content, their thickness, their hardness and their sclerophylly index [10] and also by the climate in particular the temperature, moisture and precipitation [14]. Concerning the soil organisms effect, Scheu and Wolters [15] showed that fauna saprophage soil plays an indirectly dominating role the decomposition and largely influences the become of organic matter. The decomposition of litter constitutes the principal source of the nutriments for the biological activity of the soil organisms in the terrestrial ecosystems [16].

In savannahs of Ngaoundere, several work was undertaken on the litter decomposition, like those of Ibrahima et al. [17] on the leaching and the dynamics of the organic compounds of the litters of eight species of savannahs of Ngaoundere, Anguessin et al. [18] on the climate effect on the litter decomposition of Jatropha curcas and Jatropha gossypifolia in sudano savannahs of North Cameroon, of Ibrahima et al.[19] on the synergic effect of earthworms and microorganisms on the litters decomposition of six species of savannahs of Ngaoundere and Ibrahima et al. [20] on the patterns of the litter decomposition of the 24 species of savannahs of Ngaoundere. However no study was undertaken on the total effect of the soil organisms on the decomposition of the litters of the socio-economic species of Sudano-guinea savannahs of Ngaoundere Cameroon. The goal of this study is to assess the total effect of the soil organisms on the litters decomposition of the four agroforesteries species (Terminalia glaucescens, Ficus sycomorus, Hymenocardia acida and Daniellia oliveri) of Sudano-guinea savannah of Ngaoundere Cameroon.

\section{Material and Methods}

\subsection{Study Site}

This research was carried out in the locality of Bini-Dang, Guinea savannah highlands of Adamawa region. The Guinea savannah highlands area is approximately $7200 \mathrm{Km}^{2}$ and spread between the latitude $7^{\circ} 236^{\prime} \mathrm{N}$ and $13^{\circ} 34^{\prime} 12^{\prime} \mathrm{E}$. The experimental site located at the University of Ngaoundere lies in latitude $7^{\circ} 24^{\prime}$ North and longitude $13^{\circ} 32^{\prime}$ East with; the average elevation is $1079 \mathrm{~m}$. Two Plots were chosen one plot (P1) was not treated, used as control. The other one (P2) was treated with insecticid product called naphthalene that was spread on the plot a day before litter incubation to eliminate soil organisms of plot.

\subsection{Leaf Litter Selection}

The species used in the study are among the most important socio-economic tree species valued by the populations of the guinea savannah highlands. They are source of income, food, firewood, medicinal products and soil fertility indicators for the farmers of this locality $[13,19$, 28]. They involved deciduous broad-leaved including three trees (Ficus sycomorus (Miq.) Steud. ex A. Rich, Moraceae, Terminalia glaucescens Planch., Combretaceae and Daniellia oliveri (Rolfe) Hutch. and Dalziel, Caesalpiniaceae) and one shrub (Hymenocardia acida Tul., Hymenocardiaceae). The distribution area of these plant species is savannahs land.

\subsection{Methodology}

\subsubsection{Litter Decomposition Experiment in Situ}

litterfall samples were collected directly from Ngaoundere humid savannahs. Litter bags method was used according to Bocock and Gilbert [29], litterbags made up of nylon material with $2 \mathrm{~mm}$ mesh and size according to litter type to avoid leaf material compression and prevent the creation of artificial conditions [30, 31]. The $2 \mathrm{~mm}$ diameter mesh is considered by Sundarapandian and Swamy [32] to be small enough to prevent litter loss and large enough to allow access to macrofauna such as some earthworms and termites. In total, one hundred and forty-four (144) litterbags (4 species $\mathrm{x}$ 6 sampling dates $\times 3$ replications $\times 2$ plots) were filled with about $10 \mathrm{~g} \pm 0.01 \mathrm{~g}$ of litter. The experimental design was a Split-plot with three replicates. The main treatment is the plots and species are as subtreatment. Three litterbags per species were collected at 2, 4, 6, 10, 16 and 24 weeks intervals. The dry mass of the litter samples in each litterbag was determined after it was oven-dried at $60^{\circ} \mathrm{C}$ to constant mass for $48 \mathrm{~h}$.

To determine initial dry mass, three other litter samples of each species not including in the above mentioned were weighed and dried at $60^{\circ} \mathrm{C}$ to constant mass. The litter dry mass remaining was calculated per sample date and species as follow: $\mathrm{LMR}(\%)=\left(\mathrm{LDM}_{\mathrm{t}} / \mathrm{LDM}_{\mathrm{o}}\right) \times 100$, where LMR is litter dry mass remaining, $\mathrm{LDM}_{\mathrm{o}}$ is the initial litter dry mass et $\mathrm{LDM}_{t}$ is the litter dry mass of each sample at the time $\mathrm{t}$.

\subsubsection{Extraction Method the Soil Organisms}

Soil organisms were sampled according to the tropical soil biology and fertility (TSBF) method [33] at the third and sixth month of the field litter incubation. A block of soil was excavated in square frame of $20 \mathrm{~cm}$ side and $20 \mathrm{~cm}$ deep in the both plot (control and treated). The soil sample was sorted and the soil organisms were manually collected. Before soil sampling, the soil organisms were also collected on the top soil in the both plots. All the soil organisms were identified at the family level and stored in the bottles at the 
laboratory.

\subsection{Statistical Analysis and Calculation}

Following Seastedt [34] the mass loss as contributed by the soil organisms (soil organisms effect) was calculated by using the following formula:

$$
\mathrm{SOE}=((\mathrm{MC}-\mathrm{MT}) / \mathrm{MC}) \times 100
$$

Where SOE is the soil organisms effect on litter mass loss, $\mathrm{MC}$ is the mass loss of the control, MT is the mass loss of treatment.

The oven dried litter mass remaining will hereafter be denoted as LMR. The LMR values for each species were fitted to the single exponential model commonly used, assuming that the litters were composed of one compartment with the constant potential weight loss [35]:

$$
\mathrm{LMR}=\mathrm{Ae}^{-\mathrm{kt}}
$$

Where $\mathrm{A}$ is original mass, $\mathrm{k}$ is the decomposition rate constant over time $t$, and LMR is expressed as a percentage of the initial mass and the time in weeks. Half-time $\left(\mathrm{t}_{0.5}\right)$ of decomposing litter samples were estimated from the k-values using the equation of Bockheim et al. [36]:

$$
\mathrm{t}_{0.5}=\ln (0.5 /-\mathrm{k})=0.693 /-\mathrm{k}
$$

A multiple comparison among the fitted decomposition constants (k) was carried out using the T'-method [37].

Before forming any analysis, all variables were tested for normality and if necessary, log transformed. Using a one-way
ANOVA, following by Scheffe's mean comparison test at 5\% (if ANOVA was significant), we compared LMR among litter types (or species). Student $\mathrm{t}$ test was also used to compare LMR of the two plots. These tests were conducted through software package statgraphic plus, version 5.0.

\section{Results}

\subsection{Variation of Composition and Abundance of Soil Organisms During Litter Decomposition}

Table 1 presents the total taxonomic composition of the soil organisms collected during $12^{\text {th }}$ and $24^{\text {th }}$ weeks of incubation of the litters in the control and treated plots. On the whole 09 taxonomic groups were collected for the period of study, with a density and frequency variables according to the period of harvest and plot. Among the 09 groups, the ants and the termites are most numerous, with the densities higher than 108 individuals $/ \mathrm{m}^{2}$, followed by that of the earthworms $\left(>27\right.$ ind.$\left./ \mathrm{m}^{2}\right)$ in the two plots. The other groups present a density lower than 17 individuals $/ \mathrm{m}^{2}$ whatever the selected plot.

Density and the frequency of each group of soil organisms, as well as the total density of the control plot (P1) are higher than those of the treated plot (P2). Enchytraeids are completely eliminated from the treated plot and certain taxonomic groups like the Woodlice, Diplopods and Centipedes knew a strong reduction in this treated plot, with respective rates of reduction in $62.69 \%, 69.88 \%$ and $80.95 \%$

\begin{tabular}{|c|c|c|c|c|c|}
\hline \multirow{2}{*}{ Category } & \multirow{2}{*}{ Soil organisms } & \multicolumn{2}{|l|}{ Control plot } & \multicolumn{2}{|l|}{ Treated plot } \\
\hline & & D (ind./m ${ }^{2}$ ) & F (\%) & D (ind./ $\mathbf{m}^{2}$ ) & F (\%) \\
\hline \multirow[t]{2}{*}{ Mesofauna } & Mites & 12.50 & 2.58 & 7.50 & 2.44 \\
\hline & Enchytraeids & 1.25 & 0.26 & 0.00 & 0.00 \\
\hline \multirow[t]{6}{*}{ Macrofauna } & Earthworms & 38.75 & 7.99 & 27.50 & 8.94 \\
\hline & Diplopods & 12.50 & 2.58 & 3.75 & 1.22 \\
\hline & Ants & 206.25 & 42.53 & 140.00 & 45.53 \\
\hline & Termites & 181.25 & 37.37 & 108.75 & 35.37 \\
\hline & Woodlice & 10.00 & 2.06 & 3.75 & 1.22 \\
\hline & Total & 485.00 & 100 & 307.50 & 100 \\
\hline
\end{tabular}
compared to the control plot.

Table 1. Overall taxonomic composition of soil organisms in the two plots.

Density (D), frequency (F) and individuals (ind.).

The density and the frequency of the taxonomic groups of soil organisms vary according to the period of harvest in the two plots (Table 2). The most abundant groups consist of ants and termites, with frequency varying from $17.70 \%$ to $55.75 \%$ in the treated plot at the $24^{\text {th }}$ week. The least abundant in the two plots are of the enchytraeids and the centipedes at the beginning of the incubation of litters $\left(12^{\text {th }}\right.$ week) and of enchytraeids, Centipedes and the Woodlice at the end of the incubation of litters $\left(24^{\text {th }}\right.$ week $)$, with frequency lower than $2 \%$. In the two plots, the density of all these taxonomic groups decreases with the time of incubation of litters, except for that of the collembola, which passes from 15 to 20 individus $/ \mathrm{m}^{2}$ between the beginning and the end of the incubation of litters in the treated plot.

The density of the soil organisms varies between the two plots according to the taxonomic group and the incubation period of litters (Table 2). The mites, the earthworms, the diplopods and the ants are abundant in the treated plot than in that control whatever the incubation period of litters. On the other hand, the density of the enchytraeids, the termites, the woodlice and the total density of the soil organisms are higher in the control plot than in that treated whatever the 
incubation period of litters. The centipedes present a variable behavior according to the incubation period of the litters. Their density in the treated plot is higher than that of the control plot at the beginning of the incubation of litter $\left(12^{\text {th }}\right.$ week), whereas this density in the treated plot is lower than that of control at the end of the incubation of litters $\left(24^{\text {th }}\right.$ week).

Table 2. Taxonomic composition of soil organisms in the two plots according to the period of litter incubation in the field.

\begin{tabular}{|c|c|c|c|c|c|c|c|c|c|}
\hline \multirow{3}{*}{ Category } & \multirow{3}{*}{ Organisms } & \multicolumn{4}{|l|}{12 weeks } & \multicolumn{4}{|l|}{24 weeks } \\
\hline & & \multicolumn{2}{|l|}{ Control plot } & \multicolumn{2}{|l|}{ Treated plot } & \multicolumn{2}{|l|}{ Control plot } & \multicolumn{2}{|l|}{ Treated plot } \\
\hline & & D (ind./m²) & F (\%) & D (ind./m²) & $F(\%)$ & D (ind./m²) & $F(\%)$ & D (ind./m $\left.\mathbf{m}^{2}\right)$ & F (\%) \\
\hline \multirow[t]{3}{*}{ Mesofauna } & Mites & 7.50 & 1.44 & 2.50 & 0.75 & 17.50 & 3.89 & 12.50 & 4.42 \\
\hline & Collembola & 17.50 & 3.36 & 10.00 & 3.01 & 15.00 & 3.33 & 20.00 & 7.08 \\
\hline & Enchytraeids & 2.50 & 0.48 & 0.00 & 0.00 & 0.00 & 0.00 & 0.00 & 0.00 \\
\hline \multirow[t]{7}{*}{ Macrofauna } & Earthworms & 35.00 & 6.73 & 22.50 & 6.77 & 42.50 & 9.44 & 32.50 & 11.50 \\
\hline & Diplopods & 10.00 & 1.92 & 0.00 & 0.00 & 15.00 & 3.33 & 7.50 & 2.65 \\
\hline & Centipedes & 5.00 & 0.96 & 2.50 & 0.75 & 7.50 & 1.67 & 0.00 & 0.00 \\
\hline & Ants & 175.00 & 33.65 & 122.50 & 36.84 & 237.50 & 52.78 & 157.50 & 55.75 \\
\hline & Termites & 252.50 & 48.56 & 167.50 & 50.38 & 110.00 & 24.44 & 50.00 & 17.70 \\
\hline & Woodlice & 15.00 & 2.88 & 5.00 & 1.50 & 5.00 & 1.11 & 2.50 & 0.88 \\
\hline & Total & 520.00 & 100.00 & 332.50 & 100.00 & 450.00 & 100.00 & 275.00 & 100.00 \\
\hline
\end{tabular}

Density (D), frequency (F) and individuals (ind.).

\subsection{Litter Decomposition}

\subsubsection{Dynamics of Dry Mass of Remaining Litter}

The dynamics of litter mass loss in two plots (with and without soil organisms) was slowed at the beginning of the litter decomposition experiment and fasted over time for all plant species (Figure 1). The patterns of LMR dynamics differed among plant species in each of the two plots. They were the fastest in F. sycomorus and the slowest in $T$. glaucescens for both treatments. In each of four plant species, patterns of LMR dynamics differed significantly between treatments according to sampling date (Figure 1). The mean Patterns of dynamics of LMR including all plant species varied between treatments and were slower without soil organisms than that of control (Figure 2). For each of these sampling dates, the litter mass remaining was significantly lower for treated plot than that of control plot.

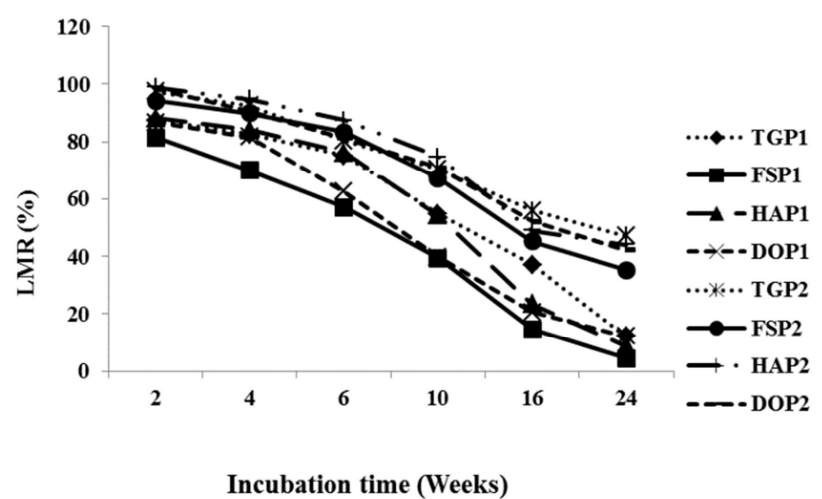

Figure 1. Dynamics of the dry mass remaining (\%) from four plant species during a time course of 24 weeks of litter incubation in control (P1) and treated (P2) plots; T. glaucescens (TG), F. sycomorus (FS), H. acida (HA) and D. oliveri $(D O)$.

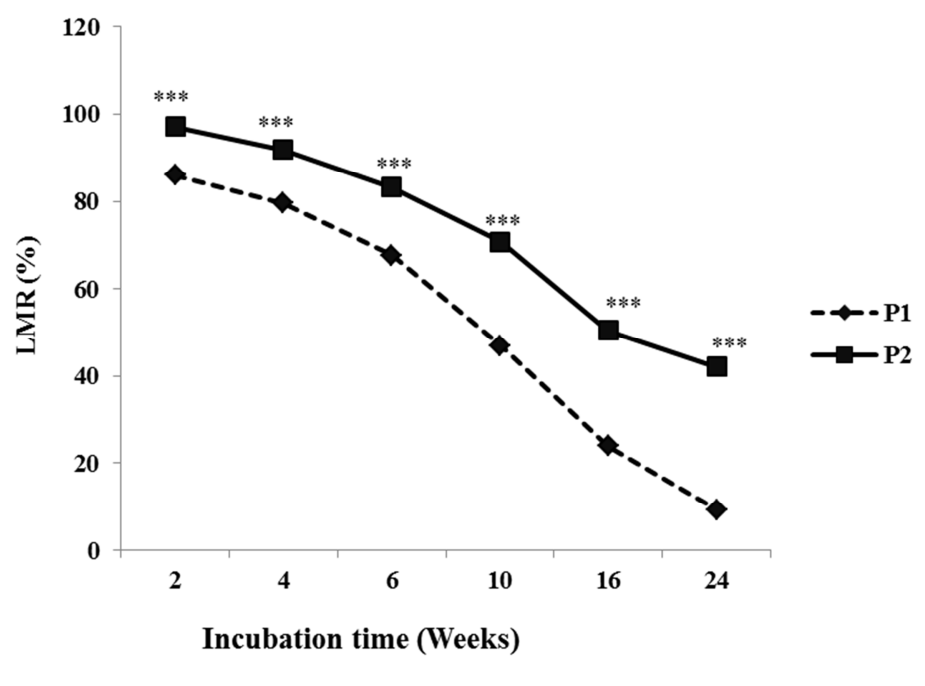

Significance at: $* * *: \mathrm{P}<0.001$.

Figure 2. Dynamics of average dry mass remaining (\%) of all the litters including during a time course of 24 weeks of litter incubation in control (P1) and treated (P2) plots. 
At the end of the experiment ( 24 weeks), the average of litter mass remaining including all plant species differed significantly $(\mathrm{t}=0.67, \mathrm{P}<0.001)$ between treated and control plots. The value was lower for treated plot $(9.00 \%)$ than that of control plot $(42.00 \%$ of initial dry mass). The corresponding mass loss values were 91.00 and $58.00 \%$. According to each plant species varied from 44.46 in $F$. sycomorus to $58.18 \%$ of initial dry mass in T. glaucescens in control plot, and from $69.16 \mathrm{~F}$. sycomorus to $74.82 \% \mathrm{H}$. acida in treated plot (Table 3 ). Thus, the corresponding mass loss was between 55.54 and $41.82 \%$ and between 30.84 and $25.18 \%$ respectively for treated and control plots. The differences between species were not significant in the two plots.

Table 3. Litter dry mass remaining (LMR) in percentage of initial mass after 24 weeks of incubation time in treated and control plots. Standard deviation in parenthesis.

\begin{tabular}{lllll}
\hline Plots & TG & FS & HA & DO \\
\hline Control & $58,18(27,70)^{\mathrm{a}}$ & $44,46(29,00)^{\mathrm{b}}$ & $55,81(31,38)^{\mathrm{b}}$ & $50,58(29,86)^{\mathrm{b}}$ \\
Treated & $73,92(18,98)^{\mathrm{a}}$ & $69,16(23,07)^{\mathrm{a}}$ & $74,82(22,37)^{\mathrm{a}}$ & $0,76^{\text {ns }}$ \\
t Student & $3,95^{\mathrm{ns}}$ & $7,99^{* *}$ & $4,37^{*}$ & $0,24^{\text {ns }}$ \\
\hline
\end{tabular}

Terminalia glaucescens (TG), Ficus sycomorus (FS), Hymenocardia acida (HA), Daniellia oliveri (DO). Values with the same letters indicate that species are not significantly different. ns: not significant, significant at $*: \mathrm{P}<0,05 ; * *: \mathrm{P}<0,01$.

\subsubsection{Litter Decomposition Rate Constants}

The LMR of each of the four plant species was fitted to negative exponential model, with highly significant $(\mathrm{P}<$ 0.001 ) coefficient of determination for all species in the both treatments to determine the litter decomposition rate constants $(k)$ and the corresponding half-life $\left(t_{1 / 2}\right)$. A multiple comparison of litter decomposition rate constants (k) by $T^{\prime}$-method showed that the rate constants $(\mathrm{k})$ of litter decomposition varied among plant species and between treatments (Figure 3). The values of $\mathrm{k}$ ranged from 0.042 to 0.072 week $^{-1}$ in treated plot and from 0.063 to 0.096 week $^{-1}$ in control plot (Figure 3). The litters of $F$. sycomorus showed the fastest decomposition in the two plots $\left(0.096\right.$ and 0.072 week $\left.^{-1}\right)$, those of T. glaucescens and $H$. acida the slowest ones respectively in control $\left(0.063\right.$ week $\left.^{-1}\right)$ and treated $\left(0.042\right.$ week $\left.^{-1}\right)$ plots. The litter decomposition was faster in control plot than in treated plot, excepted $T$. glaucescens which has the same value of $\mathrm{k}$ in the two plots.

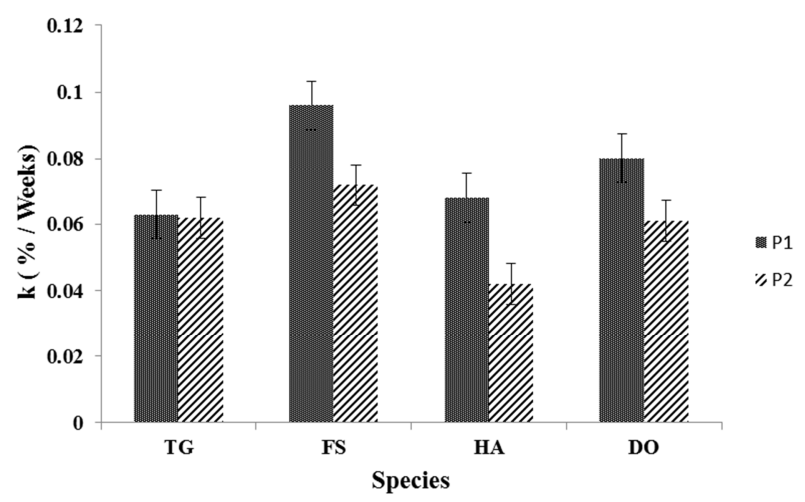

Figure 3. Litter decomposition rate constants $(k)$ of four plant species in control (P1) and treated (P2) plots. T. glaucescens (TG), F. sycomorus (FS), H. acida (HA) and D. oliveri (DO).

The corresponding half-life $\left(\mathrm{t}_{1 / 2}\right)$ of litter decomposition ranged from 07.34 to 29.79 weeks in treated plot and from 16.84 to 47.45 week in control plot (Figure 4). The lowest half live of decomposition was found in F. sycomorus in bot plots and the highest ones in T. glaucescens and $H$. acida respectively in control and treated plots. The half-life of litter decomposition of all species was higher in treated plot than in control plot.

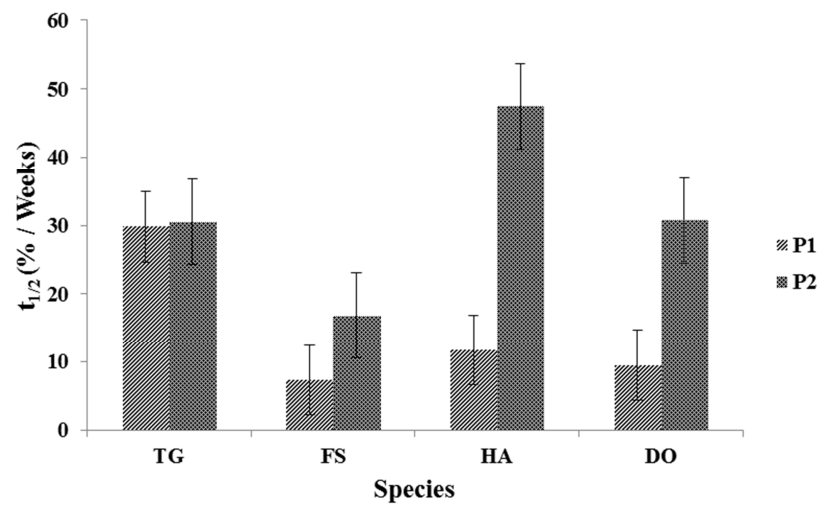

Figure 4. Half-time $\left(t_{1 / 2}\right)$ of litter décomposition of four plant species in control (P1) and treated (P2) plots. T. glaucescens (TG), F. sycomorus (FS), H. acida (HA), D. oliveri (DO).

\subsubsection{Contribution of Soil Organisms to Litter Decomposition}

Relative contributions of soil organisms to litter mass loss varied according to species (Figure 5). This contribution ranged from $43.75 \%$ to $53.76 \%$ of litter mass loss. The soil organisms contribution to litter mass loss was highest for litter of $H$. acida $(53.76 \%)$, the lowest for that of $T$. glaucescens $(43.75 \%)$, and intermediary for the two other plant species. The effects of soil organisms appeared for all species and varied with time course of litter decomposition (Figure 6). These effects decreased slowly from the beginning to the end of the experiment. At the beginning of the experiment (second weeks), the dry mass loss due to soil organisms was $79.19,66.55,90.91$ and $87.33 \%$ respectively in T. glaucescens, F. sycomorus, H. acida, and D. oliveri, while at the end of the experiment $\left(24^{\text {th }}\right.$ week), this dry mass loss was $39.63,32.08,38.65$, and $34.14 \%$ in the same order species. 


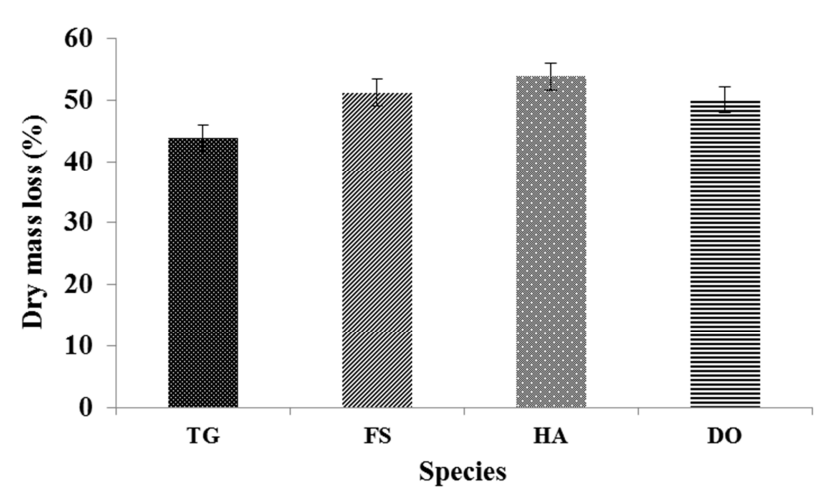

Figure 5. Effects of soil organisms to litter decomposition of four plant species in the end of incubation time (24 weeks). T. glaucescens (TG), F. sycomorus (FS), H. acida (HA), and D. oliveri (DO).

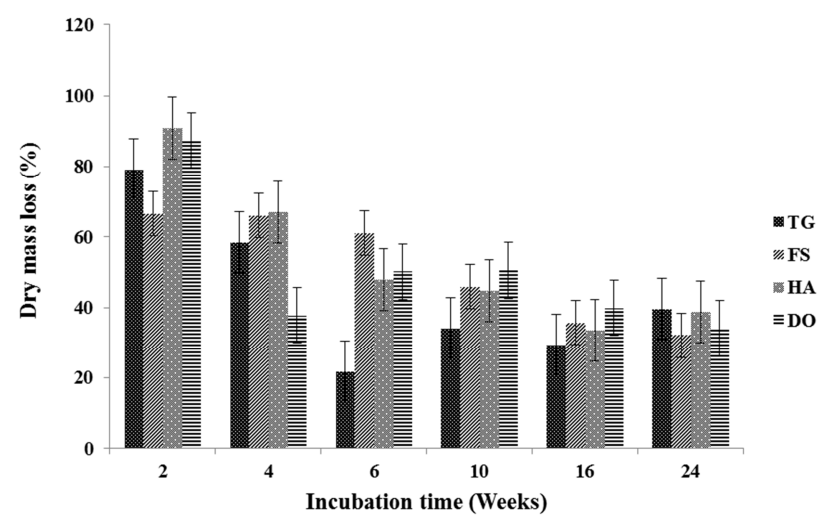

Figure 6. Effects of soil organisms to litter decomposition of four plant species according T. glaucescens (TG), F. sycomorus (FS), H. acida (HA), and D. oliveri $(D O)$.

\section{Discussion}

\subsection{Soil Organism Dynamics}

On the whole 9 taxonomic groups were collected during the study period, with a variation of density and frequency according to the period of harvest and plot. Among the 9 groups, the termites and the ants are the most abundant in the two plots, with densities varying respectively between 122 and 252 individuals $/ \mathrm{m}^{2}$ and 167 and 175 individuals $/ \mathrm{m}^{2}$, followed by that of the earthworms, with a value range from 22 to 35 individuals $/ \mathrm{m}^{2}$. The other groups of soil organisms have a low density; less than 16 individuals $/ \mathrm{m}^{2}$ in the control plot. Similar results were already reported by Lavelle, [38], Chotte et al., [39], Mando et al., [40] and Ouédraogo et al., [41] which showed that the macrofauna constitute most abundant group in African savannahs, with a predominance of the termites and ants, followed by earthworms. Dosso et al., [42, 43, 44] has reported that the termites present an ecological plasticity and a diversified diet, making them the greatest groups in the tropical ecosystems.

However, in terms of density, the values obtained in our study are lower than those of the preceding authors, except that of the ants. Indeed, density of the termites, ants and earthworms found by Chotte et al., [39] are respectively 192 to 1111 ind. $/ \mathrm{m}^{2}, 16$ to 176 ind. $/ \mathrm{m}^{2}$ and 44 to $125 \mathrm{ind} . / \mathrm{m}^{2}$. This could be explained by the difference of the sites of studies and the methodologies used in the two studies. The harvest of the soil organisms in our study was carried out using two blocks of $20 \mathrm{~cm}$ on side and $20 \mathrm{~cm}$ depth square ground in two plots, was treated and control, where the litterbags are deposited. Whereas in the studies of Chotte et al., [39], the soil organisms are inventoried in several $25 \mathrm{~cm}$ on side and $30 \mathrm{~cm}$ depth square monoliths along the transect of $50 \mathrm{~m}$ each one in soudanian savannahs of Senegal.

The density and frequency of soil organisms decrease with the time of incubation for all the inventoried organisms. This may be explain by the fact that the abundance of the soil organisms is partly related to the quantity of the food resources available in the mediums as observed by Mando et al., [40] and Ouédraogo et al.,[41]. Indeed, the quantity of the litters deposited at the beginning in the experimental plot and which attract these organisms, in particular the termites and the ants decreases with the incubation time.This result is supported by those of Maha Ali et al., [45] who reported that the number of decomposers decreases for the three periods of sampling during the litter decomposition of jatropha curcas in the field. This trend of variation and succession might be due to the recognition of fauna to litter that represent a food source for them to utilize and flourish. Li et al., [46], noticed a similar trend upon studying the interaction between decomposing litter and soil fauna in a Chinese forest ecosystem.

The density and the frequency of the soil organisms differ between the two plots. Soil organism density is lower in the treated plot with naphthalene than in the control plot and this could be explained by the effect of naphthalene which reduces the density of pedofauna. Similar results were reported by Gonzalez \& Seastedt, [47] who found in their studies on the fauna effect on the litter decomposition in zone of forest tropical and subalpine, that the control plot presents a higher density of the soil organisms than that of the treated plot. They concluded that this difference of the soil organisms between the two plots, control and treated is explained by the action of the insecticides naphtalenes applied in the treated plot. However our results show that naphthalene does not completely destroy the soil organisms in the treated plot like already showed by Bernhard-reversat, [48] in its studies on the litter decomposition in ombrophilous forest of low Coted'Ivoire. Indeed, this author has observed that the use of the insecticide naphthalene at $2 \mathrm{~kg} / \mathrm{m}^{2}$ during 140 days does not eliminate the arthropods completely, but this elimination is about 50 to $80 \%$ during the dry season, and 30 to $50 \%$ during the rainy season. Witkamp \& Crossley [49] had also used several application of $100 \mathrm{~g} / \mathrm{m}^{2} /$ week of naphthalene in the soil and obtain a reduction of $80 \%$ of the soil fauna.

\subsection{Effects of Soil Organisms on Leaf Litter Decomposition}

At this period, the loss of dry mass of the litters change according to the incubation period on the field, with an increase of dried mass loss at the beginning of the experiment for all the species whatever the plot of study. These results confirm those of Diallo et al., [50] on their studies on the mineralization of nitrogen to the course decomposition of 
litters of some tropical vegetable species and those of Ibrahima et al., [51, 17]; Massai et al., [52] on the litter decomposition of some species in Sudano-guinea savannahs of Ngaoundere, Cameroon. These authors showed that the reduction in the mass of litter is related to time of incubation and the rate of this loss of mass is fast at the beginning of the experiment, then decreases towards the end of this one. The acceleration of the litters mass loss at the beginning of the experiment is due to the fast release of the water-soluble compounds. This phase is followed by that of slow release of the recalcitrant compounds which requires the intervention of the soil organisms for their mineralization [31].

The litter decomposition is controlled by various factors of which by the soil organisms and more especially by the macrofauna and the microarthropods [53, 39, 19]. Indeed, Gonzalez \& Seastedt [47] showed that the soil organisms influence the loss mass of the litters and the rate of their decomposition. The results overtake to those of the preceding authors. Indeed, the average of mass loss by species are significantly higher in the control plot than in that treated, except those of litter of $T$. glaucescens which does not present a significant difference between the two plots. Thus the soil decomposers contribute to the acceleration of the rate of decomposition of the species of savannahs of Ngaoundere by their abundance in the control plot, but this contribution varies with the type of litter. According to Zimmer \& Topp [54], the soil organisms transform part of the litter into fecal pellets thus providing a favorable environment with the microorganisms which generally increase the rate of decomposition of the litters by the increase of their biological activities. Maha Ali et al., [45] also showed that the population density of decomposers fauna including Collembola, mites and termites was noticed to exert a significant impact on litter mass loss of Jatropha curcas. García Palacios et al., [55] indicated that soil fauna consistently enhanced litter decomposition at both global and biome scales. Litter decomposition varied among plant species. However, between these four species the statistical analyses also show that the mass losses of the litter was higher in Ficus sycomorus litter and weakest in Terminalia glaucescens litter in the two plots. According to Mapongmetsem [56], these results reveal that the losses in mass of the litters vary according to the studied species.

Broadly highest rate of decomposition between these two plots are in the control plot for all the four studied species.Rate of decomposition of these species show us that, the fastest rate are found in the litter of Ficus sycomorus and weakest rate in the Terminalia glaucescens litter in the two plots. The values of half-time are a function to the rate of decomposition, more the rate is low more the half-time is high. This result is in agreement with those of Ibrahima et al., [57] which obtained the high half-time for the litters that have a low rate of decomposition.

\section{Conclusion}

The results from this study indicate that the termites, the ants, the lombrics and the collembola are the various groups involved in the litters decomposition of Terminalia glaucescens, Ficus sycomorus, Hymenocardia acida and Daniellia oliveri. The control plot presents higher fauna than that of treated plot. The control plot presents also the total most significant organisms compared to the treated plot.

At 24 weeks of incubation on the field, the remaining dry masses of litters between the plots was very significantly $(\mathrm{t}=$ 1.97; $\mathrm{P}<0.001)$. It would appear that, the highest masses losses are found in the control plot where the activity of the soil organisms is high. The soil organisms have more effect at the beginning of experiment than at the end of incubation and act more on the litters of Ficus sycomorus and Daniellia oliveri whatever the plot of study. This study show the implication of preserving soil biodiversity in savannah of Adamawa region Cameroon for improving sustainable management of soil.

\section{References}

[1] Bellefontaine R., Petit S., Pain-Orcet M., Deleporte P. \& Bertauld J. G., 2001. Les arbres hors forêts: vers une meilleure prise en compte. Archives de documents de FAO Departements des Forêts. Paris $16 \mathrm{p}$.

[2] Mapongmetsem P. M., Nkongmeneck B. A., Rongoumi G., Dongock D. \& Dongmo B., 2011. Impact des systèmes d'utilisation des terres sur la conservation de Vitellaria paradoxa gaertn. f. (Sapotaceae) dans la région de des savanes soudano-guinéennes. International journal of environnemental studies, 68 (6): 51-72.

[3] Peltier R., Njiti F., Ntoupka M., Manlay R., Henry M. \& Morillon V., 2007. Evaluation du stock de carbone et la reproduction en bois d'un parc à karités du Nord-Cameroun, Bois Forêts des tropiques, 294 (4): 16-50.

[4] Mapongmetsem P. M., 2006. Domestication of Vitex madiensis in the Adamaoua highlands of Cameroon: phenology and propagation. AKDENIZ ÜNIVERSITESI ZIRAAT FAKÜLTESI DERGISI. pp. 269-278.

[5] Tchotsoua M., Esoh E., Mohamadou G. \& Ngana J. P., 1998. Diagnostic de l'état de l'environnement de Ngaoundéré et contribution pour une approche de gestion. Annales de la Faculté des Arts, Lettres et Sciences Humaines de l'Université de Ngaoundéré, 1: 99-144.

[6] Chapin F. S. I., Zavaleta E. S., Eviner V. T., Naylor R. L., Vitousek P. M., Reynolds H. L., Hooper D. U., Lavorel S., Sala O. E., Hobbie S. E., Mack M. C., \& Díaz S., 2000. Consequences of changing biodiversity. Nature, 405: 234242 .

[7] Manlay R., 2000. Dynamique de la matière organique à l'échelle d'un terroir agro-pastoral de la savane ouest-africaine (Sud-Sénégal). Thèse Doctorat ès sciences de l'environnement. Ecole Nationale du Génie Rural, des Eaux et Forêts. Université de Montpellier, 246 p.

[8] Megueni C., Awono E. T. \& Ndjouenkeu R., 2011. Effet simultané de la dilution et de la combinaison du Rhizobium et des mycorhizes sur la production foliaire et les propriétés physico-chimiques des jeunes feuilles de Vigna unguiculata (L.) Walp. Journal of Applied Biosciences, 40: 2668-2676. 
[9] Singh G., Singh B., Kuppusamy V. \& Bala N., 2002. Variations in foliage and soil nutrient composition in Acacia tortilis plantation of different ages in North-West Rajasthan. Indian Forest, 128: 514-521.

[10] Chapin F. S., Matson P. A. \& Mooney H. A., 2002. Principles of terrestrial ecosystem ecology. Springer-Verlag, New York Inc. pp. 234-242.

[11] Begon M., Arpin P., Ponge J. F. \& Vannier G., 2005. An introduction to the ecological relations between organisms and their environment sat the ecosystem and community levels of organization. Topics include primary production and decomposition, migration and dispersal across lands capes, and food webs. Blackwell Publishers, Oxford UK.

[12] Bossa J. R., Adams J. F., Shannon D. A. \& Mullins G. L., 2000. Phosphorus and potassium release pattern from Leucaena leaves in three environment of Haiti. Nutrients Cycling in Agroecosystems, 73: 25-35.

[13] Ibrahima A., Nguetnkam J.-P., Pabame P., Beunon T. \& Guidawa G., 2007. Soil Degradation in the Sudano-guinea Savannas of Mbe, Cameroon: Farmers' Perception, Indicators and Soil Fertility Management Strategies. Research Journal of Agriculture and Biological Sciences, 3 (6): 907-916.

[14] Coûteaux M. M., Bottner P. \& Berg B., 1995. Litter decomposition, climate and litter quality. Trends in Ecology \& Evolution, 10: 63 - 66.

[15] Scheu S. \& Wolters V., 1991. Influence of fragmentation and bioturbation on the decomposition of $\mathrm{C} 14$ labeled beech leaf litter. Soil Biology \& Biochemistry, 23: 1029-1034.

[16] Hoorens B., Coomes D. \& Aerts R., 2010. Neigh bour identity hardly affects litter-mixture effects on decomposition rates of New Zealand forest species. Oecologia, 162: 479-489.

[17] Ibrahima A., Nguetnkam J.-P., Hamawa Y., Todou G., Wanyaola B. \& Doba R., 2003. Water absorption and leaching dynamics of litters of nine multipurpose species of the Sudano-guinea savannahs of Adamawa, Cameroon. Cam. J. Ac. Sci., 3 (1): 35-45. French.

[18] Anguessin B., Ibrahima A. \& Mapongmetsem P. M., 2017. Litter quality and decomposition along climatic gradient in northern Cameroon. International Journal of Applied Research, 3 (10): 32-38.

[19] Ibrahima A., Adda Magouo D., Ibrahima O. \& Hassana B., 2017. Synergistic effects of earthworms and soil microorganisms on litter decomposition in Sudano-guinea savannah zone of Ngaoundere Cameroun. International Journal of Agricultural Research, Sustainability, and Food Sufficiency, 4 (1): 133-150.

[20] Ibrahima A, Souhore P. \& A Mang A Menick A., 2019. Patterns of leaf litter decomposition as related to litter traits in the Sudano-guinea savannahs of Ngaoundere, Cameroon. Journal of Agriculture and Ecology Research International, 18 (1): 1-19.

[21] Suchel J. B., 1971. The distribution of rainfall and rainfall patterns in Cameroon. African Research Center, Federal University of Cameroon.

[22] Quarry M., 1989. Sahelian plant communities in Mauritania (Kaédi region), analysis of annual herbaceous cover replenishment. PhD Thesis, University of Paris Sud Orsay, IE. M. V. T. Maisons-Alfort, CENERV. Nouakchott. 238 p. French.
[23] Hengue P., 1994. General report on the environmental problem in the province of Adamawa. Regional consultation on the environment for the province of Adamawa; $p$ 7. French.

[24] Belinga G., 2000. Degradation of cultivated soils in North Cameroon, inventory and identification of endogenous indicators and techniques used by peasants: case of MafaKilda territory, FASA brief, Dschang. 320 p. French.

[25] Brabant P. \& Humbel F. X., 1974. "Explanatory note of the pedological map of Poli, No. 51, Map at 1 / 50000th", Yaoundé. French.

[26] Letouzey R., 1968. Phytogeographic study of Cameroon. Paul de Chevalier (ed.), Paris V ${ }^{\text {th }}$, France. 551p. French.

[27] Yonkeu S., 1993. Vegetation of the pastures of Adamawa (Cameroon): ecology and pastoral potential. $\mathrm{PhD}$ thesis, University of Rennes I, France. 207 p. French.

[28] Massai Tchima J., Ibrahima A., Ngakou A., Babe Ndara G., Maigari P., Mamadou Laminou M. A., 2019. Woody species indicator of soil fertility and their socio-economic value in the sudano-guinea savannahs of Ngaoundere, Adamawa Cameroon. International Journal of Natural Resource Ecology and Management, 4 (6): 216-223.

[29] Bocock K. \& Gilbert O., 1957. The disappearence of leaf litter under different woodland conditions. Plant and Soil, 9: 179-185.

[30] Swift M. J., Heal O. W. \& Anderson J. M., 1979. Decomposition in terrestral ecosystems. Blackwell scientific publication. Studies in ecology (5). Oxford London. 372 p.

[31] Ibrahima A., 1995. Experimental and spectroscopic approaches to the decomposition of Mediterranean litter. Ph. D. from the University of Montpellier II, Montpellier, France; 185p. French.

[32] Sundarapandian S. M. \& Swamy P. S., 1999. Litter production and leaf litter decomposition of selected tree species in tropical forest sat Kodoyar in the Western Ghats, India. Forest Ecology and Management, 123: 231-244.

[33] Anderson J. M. \& Ingram J. S. I., 1993. Tropical Soil Biology and Fertility: a handbook of methods, 2a ed. Anderson, and Ingram, eds. CAB International, Wallingford, $249 \mathrm{p}$.

[34] Seastedt T. R., 1984. The role of micro arthropods in decomposition and mineralization Processes. Annual Review of Entomology, 29: 2 - 46.

[35] Gillon D., Joffre R. \& Ibrahima A., 1994. Initial properties and decay rate: a microcosm experiment on Mediterranean species. Canadian Journal of Botany, 72: 946-954.

[36] Bockheim J. G., Jepsem E. A. \& Heisey D. M., 1991. Nutrient dynamics in decomposing leaf litter of four tree species on a sandy soil in North western Wisconsin. Canadian Journal of Forestry Research, 21: 803-812.

[37] Sokal J. R. \& Rohlf R. R., 1981. Biometry. Ed Freeman, H. W. and Co, Sans Francisco, p 520.

[38] Lavelle, P. (1997). Faunal activities and soil processes: adaptive strategies that determine ecosystem function. Adv. Ecol. Res., 27: 93-132.

[39] Chotte, J.-L., Duponnois, R., Cadet, P., Adiko, C., 2001. La Jachère en Afrique tropicale. De la jachère naturelle à la jachère améliorée. Le point des connaissances, John Libbey, Paris, pp. 85-123. 
[40] Mando A., Brussaard L., Stroosnijder L. \& Brown G. G., 2002. Managing termites and organic resources to improve soil productivity in the Sahel. In: Program, Abstract and Related documents of the International Technical Workshop on Biological Management of Soil Ecosystems for Sustainable Agriculture, Brown GG, Hungria M, Olivera LJ, Bunning S, Montanez A, (eds.), Série Documentos Londrina, Bazil: 182: 191-203.

[41] Ouédraogo E., Mando A. \& Brussaard L., 2008. Termites and mulch work together to rehabilitate soils, Low external Input and Sustainable Agriculture (LEISA) Magazine, 24 (2): 28.

[42] Dosso K., Konaté S., Aïdara D. \& Linsenmair K. E., 2010. Termite diversity and abundance across fireinduced habitat variability in a tropical moist savanna (Lamto, central Côte d'Ivoire). Journal of Tropical Ecology, 26: 323-34.

[43] Dosso K., Yéo K., Konaté S. \& Linsenmair K. E., 2012. Importance of protected areas for biodiversity conservation in central Côte d'Ivoire: Comparison of termite assemblages between two neighbouring areas under differing levels of disturbance. Journal of Insect Science, 12: 131.

[44] Dosso K., Deligne J., Yéo K., Konaté S. \& Linsenmair K. E., 2013. Changes in the termite assemblage across a sequence of land-use systems in the rural area around Lamto Reserve in Central Côte d'Ivoire. Journal of Insect Conservation, 17: 1047-1057.

[45] Maha Ali AL., Ishtiag HA., 2015. Decomposition of Jatropha curcas Linn. Litter (A case study at El Rawakeeb Research Farm, Sudan). Journal of Biodiversity and Ecological Sciences, 5 (3): 205-213.

[46] Li H., Xu L., Wu F., Yang W., Ni X. \& He J., 2016. Forest gaps alter the total phenol dynamics in decomposing litter in an alpine fir forest. PLoS One 11, e0148426.

[47] Gonzalez G. \& Seastedt T. R., 2001. Soil fauna and plant litter decomposition in tropical and subalpine forests. Ecology, 82: 955-964.

[48] Bernhard-Reversat, 1972. Décomposition de la litière de feuilles en forêt ombrophile de basse COTE-D'IVOIRE, Centre ORSTOM d'Andiopodoumé, Côte d'ivoire. Oecol. plant., 7 (3): 279-300.
[49] Witkamp M. \& Crossley D. A. Jr., 1966. The role of arthropods and microflora in breakdown of white oak litter. Pedobiologia, 6: 293-303.

[50] Diallo M. D., Guissé A. \& Coundoul M., 2006. Minéralisation de l'azote in situ à partir de la décomposition de quelques litières d'espèces végétales tropicales. Journal de la Faculté des Sciences et Techniques, 4 (2): 18-28.

[51] Ibrahima A., Mapongmetsem P. M., Nguetnkam J. P. \& Longmo J., 2000. Décomposition des litières de quelques essences agroforestières en zone des savanes de l'Adamaoua, Cameroun. Biosciences proceedings, 7: 387-395.

[52] Massai T. J., Babe N. G., Maigari P., Djouka N. P., Ibrahima A., 2020. Effect of litter mixture on litter decomposition and nutrient release of three agroforestry species in SudanoGuinean savannah of Ngadoundere, Adamawa Cameroon Journal of Degraded and Mining Lands Management, 7 (2): 2065-2073.

[53] Gallardo A. \& Merino J., 1993. Leaf decomposition in two Mediterranean ecosystems of Southwest Spain: influence of substrate quality. Ecology, 74: 152-161.

[54] Zimmer M. \& Topp W., 2002. The role of coprophagy in nutrient release from feces of phytophagous insects. Soil Biology and Biochemistry, 34: 1093-1099.

[55] García-Palacios P., Maestre F. T., Kattge J., Wall D. H., 2013. Climate and litter quality differently modulate the effects of soil fauna on litter decomposition across biomes. Ecol. Lett., 16: $1045-1053$.

[56] Mapongmetsem P. M., Loura B. B., Nkongmeneck B. A., Ngassoum M. B., Gubbuk H., Baye N. C. \& Longmo J., 2005. Litter fall, decomposition and nutrients Release in Vitex doniana sweet and vitex madiensis Oliv. In the Sudano-Guinea savannah. Akdeniz universite sizira atfakultesidergisi. pp. 6375 .

[57] Ibrahima A., Schmidt P., Ketner P. \& Mohrem G. T. M., 2002. Phytomasse et cycle des nutriments dans la forêt tropicale dense humide du Sud Cameroun. Tropenbos Cameroon. Documents 9. Kribi, Cameroon. 16p. 